\title{
Nieuwe WAO-inzichten helaas voor een klein publiek
}

\author{
J.J.M. Besseling
}

Recent hebben het CBS en UWV analyses uitgevoerd op WAO-gegevens. Beide analyses zijn vernieuwend, maar helaas zijn ze nauwelijks toegankelijk voor het publiek (Selten en Copinga, Wie komen in de WAO? CBS 13 december 2002, en UWV-BIV, WAO-instroom daalt; WAO-uitstroom stijgt, 7 november 2002). Het CBS heeft door een koppeling van UWV-gegevens met andere bij het CBS beschikbare gegevens aanvullende analyses kunnen uitvoeren. Het CBS heeft de kenmerken van de WAO-instroom in 2000 vergeleken met de overeenkomstige verzekerde populatie. Dan blijkt bijvoorbeeld dat het WAO-instroomrisico voor een alleenstaande ouder ruim tweemaal zo hoog is als gemiddeld. Het WAOrisico voor een alleenstaande is een fractie hoger dan voor degene met een partner. Turkse en Marokkaanse werknemers hebben een sterk verhoogd WAO-risico. Voor bedrijfsartsen bevat de rapportage informatieve gegevens over het WAO-risico naar bedrijfsklasse. Dit wordt ook uitgesplitst naar kenmerken als leeftijd, geslacht, huishoudpositie en herkomst. Helaas ontbreekt een uitsplitsing naar bedrijfsgrootte. Die had als benchmark gebruikt kunnen worden in het jaarverslag met een verzuimanalyse dat de arbodienst vaak voor grote werkgevers maakt. Ook de afdeling beleidsinformatievoorziening sv van het UWV heeft een vernieuwende statistische analyse uitgevoerd. De aanleiding is de stabilisering van de omvang van het WAO-bestand. De vraag is wat de achtergronden zijn waardoor het WAO- volume niet meer stijgt. Daarbij is gekeken naar de WAO-instroom die is gedaald en de uitstroom die is gestegen. Nieuw in de analyse is dat berekend wordt voor hoeveel procent van de werknemers een 13e-weeksreïntegratieplan is ingediend. Dat was in $20005,05 \%$ (exclusief overheidssectoren) en het voortschrijdend jaargemiddelde was medio $20024,55 \%$. De daling van het percentage 13e-weeksreïntegratieplannen is groter dan de daling van het percentage claimbeoordelingen bij werknemers (van 2,11\% naar 2,02\%). De analyse introduceert nog een nieuw kengetal, namelijk de verhouding tussen het aantal claimbeoordelingen ten opzichte van het aantal 13e-weeksmeldingen drie kwartalen daarvoor. Ook dat percentage is gedaald van $45,1 \%$ naar $42,5 \%$.

De analyse van het CBS kunt u nalezen via internet. Het is even zoeken aangezien hij bij het CBS niet onder publicaties staat maar als doorverwijzing in het betreffende persbericht.

De resultaten van de analyses van UWV-BIV kunt $u$ alleen nalezen als $u$ beschikt over een persoonsnetwerk met de juiste sleutelfiguren binnen het UWV. De analyse is weliswaar vrijgegeven, maar niet actief beschikbaar gesteld als papieren document of als elektronische publicatie op de UWV-website. Kortom, vernieuwende inzichten over de WAO-instroom, maar kennelijk niet bedoeld voor een groot publiek, of moet ik zeggen niet voor het publiek. 